\title{
Copper ion salts of arylthiotetrathiafulvalenes: synthesis, structure diversity and magnetic properties
}

\author{
Longfei Ma, Jibin Sun, Xiaofeng Lu, Shangxi Zhang, Hui Qi, Lei Liu, Yongliang Shao \\ and Xiangfeng Shao*
}

\author{
Full Research Paper \\ Address: \\ State Key Laboratory of Applied Organic Chemistry, Lanzhou \\ University, Tianshui Southern Road 222, Lanzhou 730000, Gansu \\ Province, China \\ Email: \\ Xiangfeng Shao* - shaoxf@lzu.edu.cn \\ * Corresponding author \\ Keywords: \\ antiferromagnetic interaction; arylthio-substituted tetrathiafulvalenes; \\ charge-transfer; crystal structure; magnetic property
}

Beilstein J. Org. Chem. 2015, 11, 850-859. doi:10.3762/bjoc. 11.95

Received: 29 January 2015

Accepted: 15 April 2015

Published: 20 May 2015

This article is part of the Thematic Series "Tetrathiafulvalene chemistry".

Guest Editor: P. J. Skabara

(c) $2015 \mathrm{Ma}$ et al; licensee Beilstein-Institut. License and terms: see end of document.

\begin{abstract}
The combination of $\mathrm{CuBr}_{2}$ and arylthio-substituted tetrathiafulvalene derivatives (1-7) results in a series of charge-transfer (CT) complexes. Crystallographic studies indicate that the anions in the complexes, which are derived from $\mathrm{CuBr}_{2}$, show diverse configurations including linear $\left[\mathrm{Cu}(\mathrm{I}) \mathrm{Br}_{2}\right]^{-}$, tetrahedral $\left[\mathrm{Cu}(\mathrm{II}) \mathrm{Br}_{4}\right]^{2-}$, planar $\left[\mathrm{Cu}(\mathrm{II})_{2} \mathrm{Br}_{6}\right]^{2-}$, and coexistence of planar $\left[\mathrm{Cu}(\mathrm{II}) \mathrm{Br}_{4}\right]^{2-}$ and tetrahedral $\left[\mathrm{Cu}(\mathrm{II}) \mathrm{Br}_{3}\right]^{-}$ions. On the other hand, the TTFs show either radical cation or dication states that depend on their redox potentials. The central TTF framework on most of TTFs is nearly planar despite the charge on them, whereas the two dithiole rings on molecule 4 in complex $4 \cdot \mathrm{CuBr}_{4}$ are significantly twisted with a dihedral angle of $38.3^{\circ}$. The magnetic properties of the complexes were elucidated. The temperature-dependent magnetic susceptibility of complex $\mathbf{5} \cdot \mathrm{Cu}_{2} \mathrm{Br}_{6}$ shows the singlet-triplet transition with coupling constant $J=-248 \mathrm{~K}$, and that of $\mathbf{3} \cdot\left(\mathrm{CuBr}_{4}\right)_{0.5} \cdot \mathrm{CuBr}_{3} \cdot \mathrm{THF}$ shows the abrupt change at $270 \mathrm{~K}$ caused by the modulation of intermolecular interactions. The thermo variation of magnetic susceptibility for the other complexes follows the Curie-Weiss law, indicating the weak antiferromagnetic interaction at low temperature.
\end{abstract}

\section{Introduction}

Since firstly synthesized in 1970s [1], tetrathiafulvalene (TTF) and its derivatives have been intensively studied to explore functional organic materials [2]. Inspired by the discovery of highly conducting charge-transfer (CT) complex TTF-TCNQ [3] and the first organic superconductor (TMTSF) ${ }_{2} \mathrm{X}$ [4], the chemical modifications on TTF are traditionally aimed at the creation of organic conductors with various electronic ground states [5-10]. It has been well-defined that a subtle modification of TTF would result in a significant effect on the properties of their complexes [5-10]. For example, the complexes of EDO-TTF (4,5-ethylenedioxy-TTF) [11-15] and MeEDO-TTF (4,5-ethylenedioxy-4'-methyl-TTF) [16-19] show the distinct 
difference on electrical transport properties. Meanwhile, the modification on TTF, particularly introducing aromatic substituents onto the TTF core, is one of the key strategies to explore functional molecular materials. The resulting TTFs have been employed as electrochemically active units in supramolecular systems and/or molecular devices, which has been summarized in many reviews [20-32]. However, the incorporation of aryl groups onto the TTF core through sulfur bridges, which resulted in arylthio-substituted TTFs (denoted as Ar-STTF), has been scarcely reported due to synthetic difficulties [33-36]. Recently, we have disclosed a facile approach toward Ar-S-TTFs [37]. Crystallographic investigations indicate that Ar-S-TTFs show various molecular geometries and packing structures depending on the nature of the peripheral aryls [38,39].

The TTF-based conducting materials are mainly produced as radical cation salts by electrochemical oxidation and CT complexes by chemical oxidation with electron acceptors $[5,6]$. Most Ar-S-TTFs possess redox potentials higher than that of bis(ethylenedithio)-TTF (BEDT-TTF) [33-39]. Consequently, the complexes of Ar-S-TTFs with electron acceptors such as fullerenes [40,41] and TCNQ [42] show a neutral ground state. However, Ar-S-TTFs can be chemically oxidized by strong electron acceptors such as $\mathrm{F}_{4}$ TCNQ [42] and Keggin-type phosphomolybdic acid [43] to form CT complexes. In comparison with fullerenes and TCNQ, the inorganic salt $\mathrm{CuX}_{2}(\mathrm{X}=\mathrm{Cl}, \mathrm{Br})$ is a strong oxidant and has been used to oxidize the TTFs to form organic conductors with diverse electronic ground states [44-54]. Herein, we report the synthesis, structure, and magnetic properties of the complexes of Ar-S-TTFs (1-7, Scheme 1) with $\mathrm{CuBr}_{2}$. These complexes show diverse structures and prop-

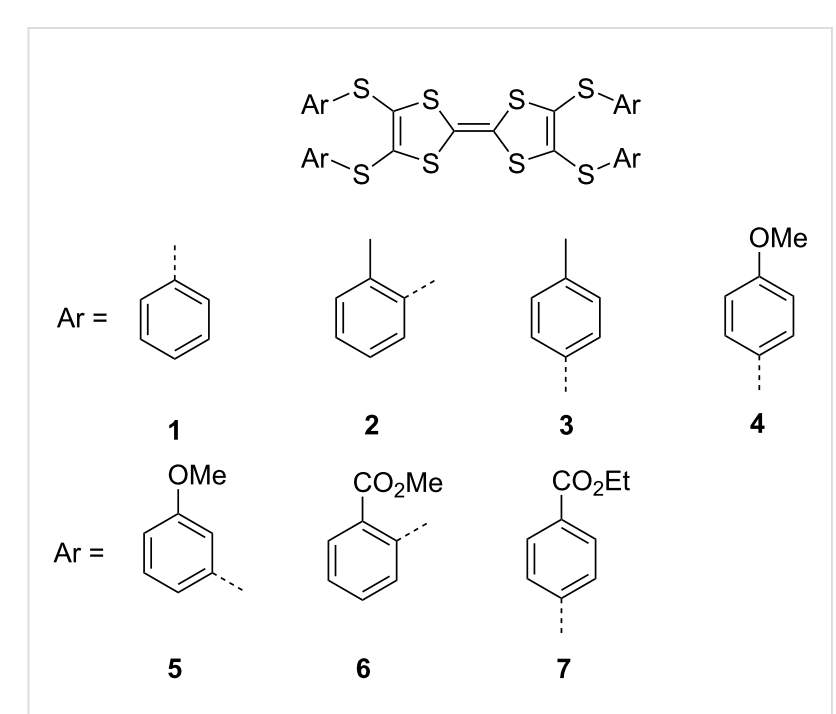

Scheme 1: Chemical structures of arylthio-substituted tetrathiafulvalenes (1-7). erties related to the oxidation state as well as the molecular geometries of TTFs.

\section{Results and Discussion Synthesis}

The donor molecules (1-7, Scheme 1) were synthesized according to our previous report $[37,38]$, and their electrochemical activities as well as the crystal structures have been fully elucidated $[38,39]$. Since the redox potentials of TTFs are very important in the formation of complexes, particularly on the charge-transfer degree, the first $\left(E_{1 / 2}{ }^{1}\right)$ and the second $\left(E_{1 / 2}{ }^{2}\right)$ redox potentials of 1-7 are summarized in Table 1. As reported in the following section, TTFs $\mathbf{1}-\mathbf{5}$ have the $E_{1 / 2}{ }^{2}<0.90 \mathrm{~V}$ and form the dicationic salts by reaction with $\mathrm{CuBr}_{2}$. On the contrary, the $E_{1 / 2}{ }^{2}$ values of $\mathbf{6}$ and 7 are higher than $0.90 \mathrm{~V}$, and these two donor molecules form the radical cation salts by reaction with $\mathrm{CuBr}_{2}$.

\begin{tabular}{|c|c|c|c|c|c|c|c|}
\hline & 1 & 2 & 3 & 4 & 5 & 6 & 7 \\
\hline$E_{1 / 2}^{1}[\mathrm{~V}]$ & 0.56 & 0.52 & 0.51 & 0.48 & 0.56 & 0.62 & 0.66 \\
\hline$E_{1 / 2}^{2}[\mathrm{~V}]$ & 0.89 & 0.85 & 0.85 & 0.83 & 0.88 & 0.95 & 0.96 \\
\hline$\Delta E[\mathrm{~V}]^{\mathrm{b}}$ & 0.33 & 0.33 & 0.34 & 0.35 & 0.32 & 0.33 & 0.30 \\
\hline
\end{tabular}

asee reference [38], and the redox potentials are recorded vs SCE; ${ }^{\mathrm{b}} \Delta E=E_{1 / 2}{ }^{2}-E_{1 / 2}{ }^{1}$.

The reaction of 1-7 with $\mathrm{CuBr}_{2}$ was performed in the mixed solvent of tetrahydrofuran-acetonitrile (THF- $\mathrm{CH}_{3} \mathrm{CN}$; v/v, 1:1) at room temperature. In the low concentration $\left(<10^{-4} \mathrm{~mol} \mathrm{~L}^{-1}\right)$, a dark green solution was formed, indicating the oxidation of 1-7 by $\mathrm{CuBr}_{2}$. When the concentration of the reaction system was increased to higher than $10^{-3}$ mol L ${ }^{-1}$, TTFs 1-7 afforded the ionic salts showing the same phase as those of the corresponding single crystalline ones. The single crystalline salts were obtained by a conventional two-phase diffusion method. In a typical procedure, the $\mathrm{CuBr}_{2}$ solution in $\mathrm{CH}_{3} \mathrm{CN}$ and the solution of TTFs in THF were placed in two different chambers of an H-shape cell, respectively. After several weeks, black single crystalline salts were formed. The compositions of the salts were determined by X-ray single crystal diffraction analyses, as summarized in Table 2 .

\section{Crystal structure}

The single crystals for all of the present salts were suitable for the X-ray single crystal diffraction analyses. Herein, we report the crystal structures of the typical salts (Figures 1-5), and those of the others are supplied in Supporting Information File 1. As mentioned above, the molecular geometries of Ar-STTF are sensitive to the environmental variations, especially the 
Table 2: Preparation, composition, yield, and appearance of the salts. ${ }^{a}$

\begin{tabular}{|c|c|c|c|c|}
\hline \multicolumn{2}{|r|}{ TTFs } & \multicolumn{3}{|c|}{ salts $^{b}$} \\
\hline & amount & composition & amount (yield) & appearance $^{c}$ \\
\hline 1 & $19 \mathrm{mg}(0.03 \mathrm{mmol})$ & 1. $\mathrm{CuBr}_{4}$ & $24 \mathrm{mg}(80 \%)$ & black needle \\
\hline 2 & 28 mg (0.04 mmol) & $2 \cdot \mathrm{CuBr}_{4}$ & 39 mg (91\%) & black needle \\
\hline 3 & 28 mg (0.04 mmol) & 3. $\left(\mathrm{CuBr}_{4}\right)_{0.5} \cdot \mathrm{CuBr}_{3} \cdot \mathrm{THF}$ & $46 \mathrm{mg}(92 \%)$ & black block \\
\hline 4 & $23 \mathrm{mg}(0.03 \mathrm{mmol})$ & $4 \cdot \mathrm{CuBr}_{4}$ & 31 mg (91\%) & black needle \\
\hline 5 & $23 \mathrm{mg}(0.03 \mathrm{mmol})$ & $5 \cdot \mathrm{Cu}_{2} \mathrm{Br}_{6}$ & $33 \mathrm{mg}(80 \%)$ & black block \\
\hline 6 & 26 mg (0.03 mmol) & 6. $\mathrm{CuBr}_{2} \cdot \mathrm{CH}_{3} \mathrm{CN}$ & $26 \mathrm{mg}(74 \%)$ & black block \\
\hline 7 & $28 \mathrm{mg}(0.03 \mathrm{mmol})$ & 7. $\mathrm{CuBr}_{2}$ & $16 \mathrm{mg}(47 \%)$ & black cuboid \\
\hline
\end{tabular}

aTTFs were dissolved in $4 \mathrm{~mL}$ of THF, and $\mathrm{CuBr}_{2}\left(100 \mathrm{mg}\right.$, dissolved in $4 \mathrm{~mL}$ of $\mathrm{CH}_{3} \mathrm{CN}$ ) was applied in the synthesis. ${ }^{\mathrm{b}}$ The compositions were determined by $\mathrm{X}$-ray single crystal diffraction analyses. 'See the photographs of the crystals in Figure S1 in Supporting Information File 1.

guest components are included in their solid-state matrix. Besides, the bond lengths and the conformation of the central TTF core are sensitive to the charge variation. The charge on TTFs can be estimated according to an empirical formula suggested by Day et al. [55], that is $\delta=(b+c)-(a+d)$. The calculated $\delta$ values and the conformation of TTFs 1-7 in neutral state and salts are summarized in Table 3 . These results indicate that 1-5 have the charge of +2 , whereas 6 and $\mathbf{7}$ are radical cations. The central TTF cores on the neutral TTFs show various conformations including chair, planar, and boat confor- mations. However, the central TTF cores of TTFs in the present salts are planar except that of $\mathbf{4}$, where the two dithiole rings are twisted with a dihedral angle of $38.3^{\circ}$. In the following, we will discuss the crystal structures of these salts, including the molecular geometry of TTFs, the structure of anions, and the packing motifs.

1. $\mathrm{CuBr}_{4}$ crystallizes in the orthorhombic $P b c n$ space group with half of molecule 1 and half of $\mathrm{CuBr}_{4}$ crystallographically unique (Figure 1a). The central TTF core on $\mathbf{1}$ is nearly planar,

Table 3: Selected bond lengths, calculated charge, and conformations of TTFs.

\begin{tabular}{|c|c|c|c|c|c|c|c|c|}
\hline & & $a[\AA]$ & $b[\AA]$ & $c[\AA]$ & $d[\AA]$ & $\delta[\AA]$ & charge & conformation \\
\hline \multirow{2}{*}{1} & neutrala & 1.325 & 1.740 & 1.737 & 1.325 & 0.827 & 0 & chair \\
\hline & complex & 1.421 & 1.689 & 1.709 & 1.367 & 0.608 & +2 & planar \\
\hline \multirow{2}{*}{2} & neutral $^{a}$ & 1.329 & 1.764 & 1.750 & 1.351 & 0.834 & 0 & planar \\
\hline & complex & 1.422 & 1.682 & 1.708 & 1.364 & 0.604 & +2 & planar \\
\hline \multirow{2}{*}{3} & neutral $^{a}$ & 1.340 & 1.757 & 1.756 & 1.333 & 0.840 & 0 & boat \\
\hline & complex & 1.418 & 1.693 & 1.704 & 1.375 & 0.604 & +2 & planar \\
\hline \multirow{2}{*}{4} & neutral $^{a}$ & 1.342 & 1.761 & 1.754 & 1.339 & 0.834 & 0 & chair \\
\hline & complex & 1.428 & 1.685 & 1.700 & 1.379 & 0.578 & +2 & twist \\
\hline \multirow{2}{*}{5} & neutral & - & - & - & - & - & - & - \\
\hline & complex & 1.429 & 1.693 & 1.710 & 1.379 & 0.595 & +2 & planar \\
\hline \multirow{2}{*}{6} & neutral $^{a}$ & 1.336 & 1.757 & 1.756 & 1.345 & 0.832 & 0 & chair \\
\hline & complex & 1.382 & 1.716 & 1.746 & 1.336 & 0.744 & +1 & planar \\
\hline \multirow{2}{*}{7} & neutral $^{a}$ & 1.34 & 1.76 & 1.76 & 1.34 & 0.84 & 0 & planar \\
\hline & complex & 1.39 & 1.71 & 1.74 & 1.35 & 0.71 & +1 & planar \\
\hline
\end{tabular}

asee reference [38]. 


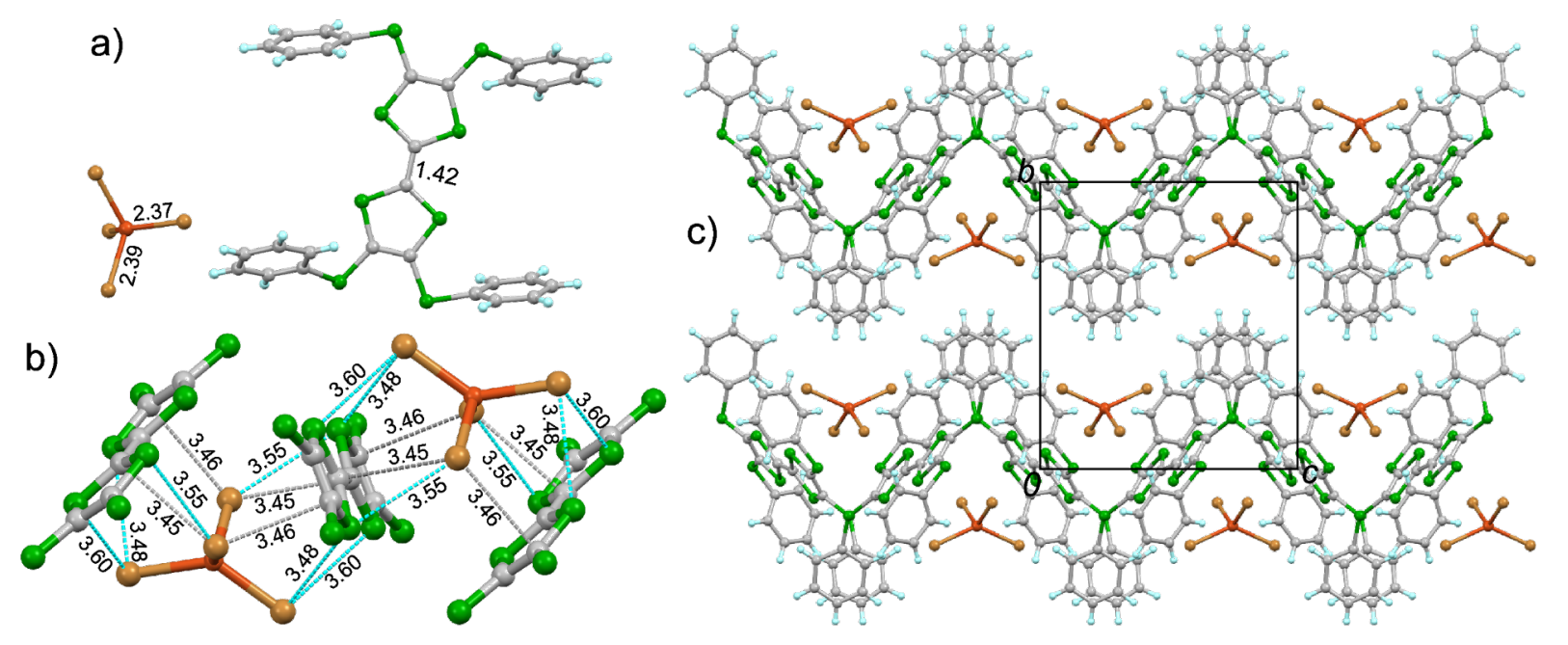

Figure 1: Crystal structure of 1.CuBr 4 : a) unit cell contents with the typical bond lengths shown (in $\AA$ ); b) interactions between the $\left[\mathrm{Cu}(I I) \mathrm{Br}_{4}\right]^{2-}$ ion and the central TTF core of 1 , where the cyan and grey dashed lines represent $B{ }^{\cdots} \cdot \mathrm{S}$ and $\mathrm{Br}{ }^{\cdots} \cdot \mathrm{C}$ contacts $(\AA)$, respectively; c) packing structure viewed along the a-axis.

which is different from the chair conformation in the neutral state. Moreover, the spatial alignment of peripheral phenyls is modulated (see Figure S2 in Supporting Information File 1). The calculated $\delta$ value of $\mathbf{1}$ is 0.608 in the salt, indicating it has the charge of +2 according to the criteria proposed by Day [55] The inorganic component $\mathrm{CuBr}_{4}$ takes the slightly distorted tetrahedral geometry. The $\mathrm{Cu}-\mathrm{Br}$ bond lengths are 2.37 and $2.39 \AA$, which are close to a typical $\mathrm{Cu}(\mathrm{II})-\mathrm{Br}$ bond length [5153,56-58]. Thus, the $\mathrm{CuBr}_{4}$ component should have the charge of -2 , consistent with the dicationic state of $\mathbf{1}$. $\mathrm{A}\left[\mathrm{CuBr}_{4}\right]^{2-}$ ion is encapsulated by two donor molecules, and there are multiple $\mathrm{Br}{ }^{\cdots} \mathrm{S}(3.48-3.60 \AA)$ and $\mathrm{Br}{ }^{\cdots} \mathrm{C}(3.45-3.46 \AA)$ close contacts [59] between the $\left[\mathrm{CuBr}_{4}\right]^{2-}$ ion and the central TTF core of 1 (Figure 1b). Donor molecules form a zig-zag chain alignment along the $c$-axis (Figure $1 \mathrm{c}$ ), and the $\left[\mathrm{CuBr}_{4}\right]^{2-}$ ion locate at the cavity formed by 1 . The spin exchange interaction between $\mathrm{Cu}(\mathrm{II})$ on $\left[\mathrm{CuBr}_{4}\right]^{2-}$ ions would take place as mediated by the $\pi$-orbitals of $\mathbf{1}$. The crystal structure of $\mathbf{2} \cdot \mathrm{CuBr}_{4}$ is reminiscent to that of $\mathbf{1} \cdot \mathrm{CuBr}_{4}$ as shown in Figure S3 and Figure S4 in Supporting Information File 1.

The crystal structure of $\mathbf{3} \cdot\left(\mathrm{CuBr}_{4}\right)_{0.5} \cdot \mathrm{CuBr}_{3} \cdot \mathrm{THF}$ at room temperature is shown in Figure 2. This salt crystallizes in the triclinic $P-1$ space group, and the asymmetric unit contains one molecule 3 , half of $\mathrm{CuBr}_{4}$, one $\mathrm{CuBr}_{3}$, and one THF. The central TTF core of $\mathbf{3}$ takes the planar conformation similar to its neutral state, whereas the spatial alignment of the 4-tolyl groups is altered (Figure S6 in Supporting Information File 1). The calculated $\delta$ value of $\mathbf{3}$ in the salt is 0.604 , indicating that 3 is oxidized to the dication form. The inorganic component
$\mathrm{CuBr}_{4}$ has a planar conformation with a $\mathrm{Cu}-\mathrm{Br}$ bond length of 2.39 and $2.43 \AA$ (Figure 1a), thus it should be dianionic. On the other hand, the oxygen atom on THF coordinates to the $\mathrm{Cu}$ atom on $\mathrm{CuBr}_{3}$ with a $\mathrm{Cu}-\mathrm{O}$ bond length of $2.08 \AA$, consequently $\mathrm{CuBr}_{3}$ takes a distorted tetrahedral conformation. The $\mathrm{Cu}-\mathrm{Br}$ bond length in $\mathrm{CuBr}_{3}$ is 2.33-2.36 $\AA$, indicating that the $\mathrm{Cu}$ atom in $\mathrm{CuBr}_{3}$ should be $\mathrm{Cu}(\mathrm{II})$. $\mathrm{A}\left[\mathrm{CuBr}_{4}\right]^{2-}$ ion is sandwiched by two donor molecules through the $\mathrm{Br}^{\cdots} \mathrm{S}$ (3.65 $\AA$ ) and Br' ${ }^{\cdots} \mathrm{C}$ contacts $(3.46-3.50 \AA)$, thus, a D-A-D type trimer of $\left[3-\mathrm{CuBr}_{4}-\mathbf{3}\right]$ is formed as shown in Figure $2 \mathrm{~b}$. The neighboring D-A-D trimers shift along the longitudinal axis of $\mathbf{3}$, thus form a voidage to accommodate one $\left[\mathrm{CuBr}_{3} \cdot \mathrm{THF}\right]$ as shown in Figure $2 \mathrm{c}$. There are $\mathrm{Br} \cdots \mathrm{S}(3.59-3.62 \AA)$ and $\mathrm{Br} \cdots \mathrm{C}$ contacts (3.44 $\AA$ ) between the $\left[\mathrm{CuBr}_{3}\right]^{-}$ion and molecule 3 in the $\mathrm{D}-\mathrm{A}-\mathrm{D}$ trimer. Consequently, the spin interaction between $\mathrm{Cu}$ (II) is expected, which would be mediated through the $\pi$-orbitals of 3 . The packing structure of this salt at low temperature $(173 \mathrm{~K})$ is very similar to that at room temperature, whereas the intermolecular interactions between the organic and inorganic components are strengthened, particularly for those between $\left[\mathrm{CuBr}_{3} \cdot \mathrm{THF}\right]$ and $\mathrm{D}-\mathrm{A}-\mathrm{D}$ timers (Figure S5 in Supporting Information File 1), which would result in the significant effect on the magnetic property as discussed in the following section.

4. $\mathrm{CuBr}_{4}$ crystallizes in the orthorhombic $P c c n$ space group with half of molecule 4 and half of $\mathrm{CuBr}_{4}$ crystallographically independent (Figure 3a). The calculated $\delta$ value of 4 in the salt is 0.578 , indicating that the charge on 4 should be +2 . The two dithiole rings of molecule 4 are significantly twisted with a 


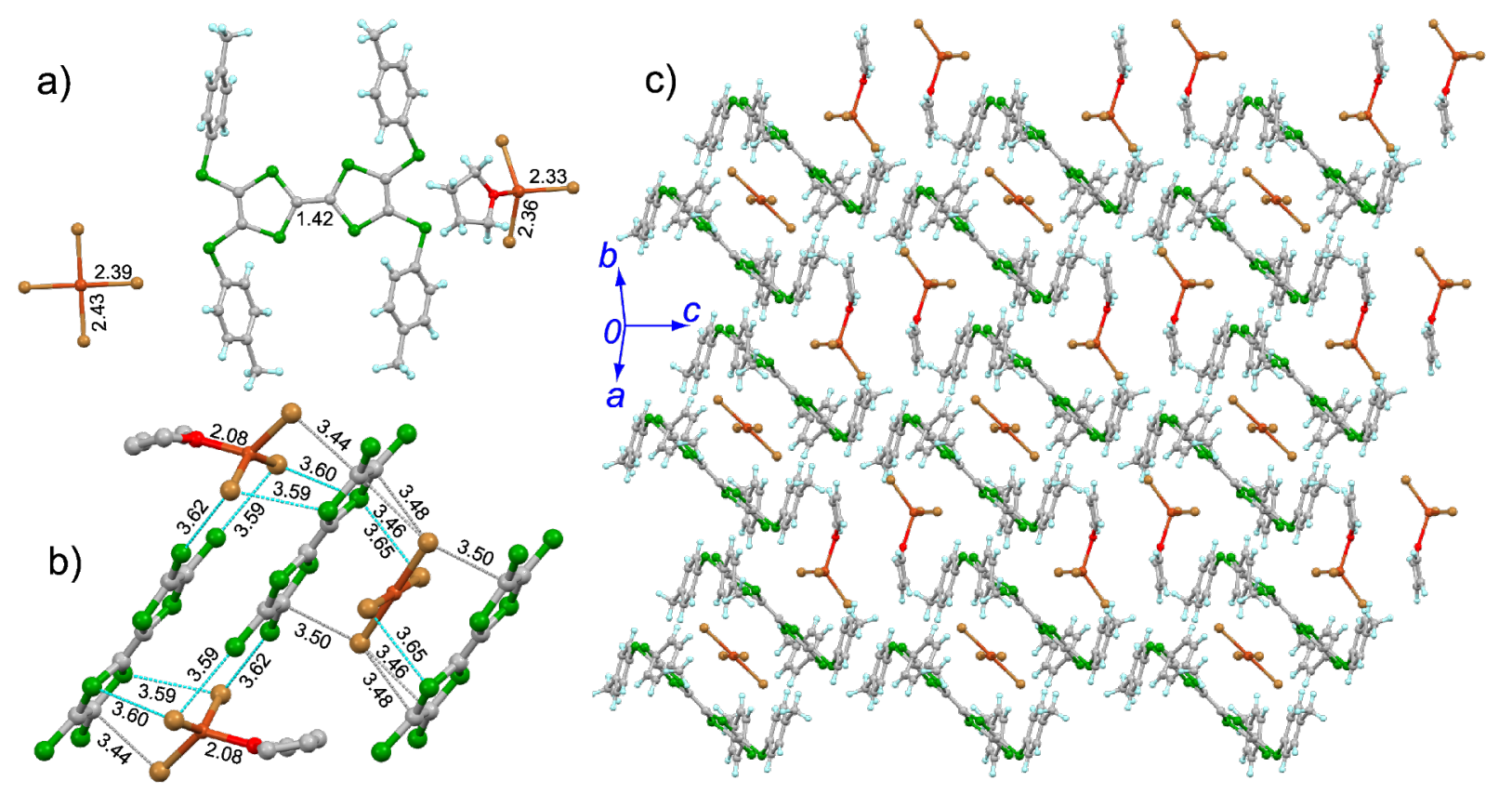

Figure 2: Crystal structure of 3. $\left(\mathrm{CuBr}_{4}\right)_{0.5} \cdot \mathrm{CuBr}_{3} \cdot \mathrm{THF}$ : a) unit cell contents with the typical bond lengths shown $(\AA)$, and the structure of planar $\left[\mathrm{Cu}(\mathrm{II}) \mathrm{Br}_{4}\right]^{2-}$ ion is generated by symmetry operation $\left.(2-x, 2-y, 1-z) ; b\right)$ interaction between the anions and the central TTF core of 3 , where cyan and grey dashed lines represent $\mathrm{Br}^{\cdots}{ }^{\mathrm{S}} \mathrm{S}$ and $\mathrm{Br}^{\cdots}{ }^{\cdots} \mathrm{C}$ contacts $(\AA)$, respectively; c) packing structure.
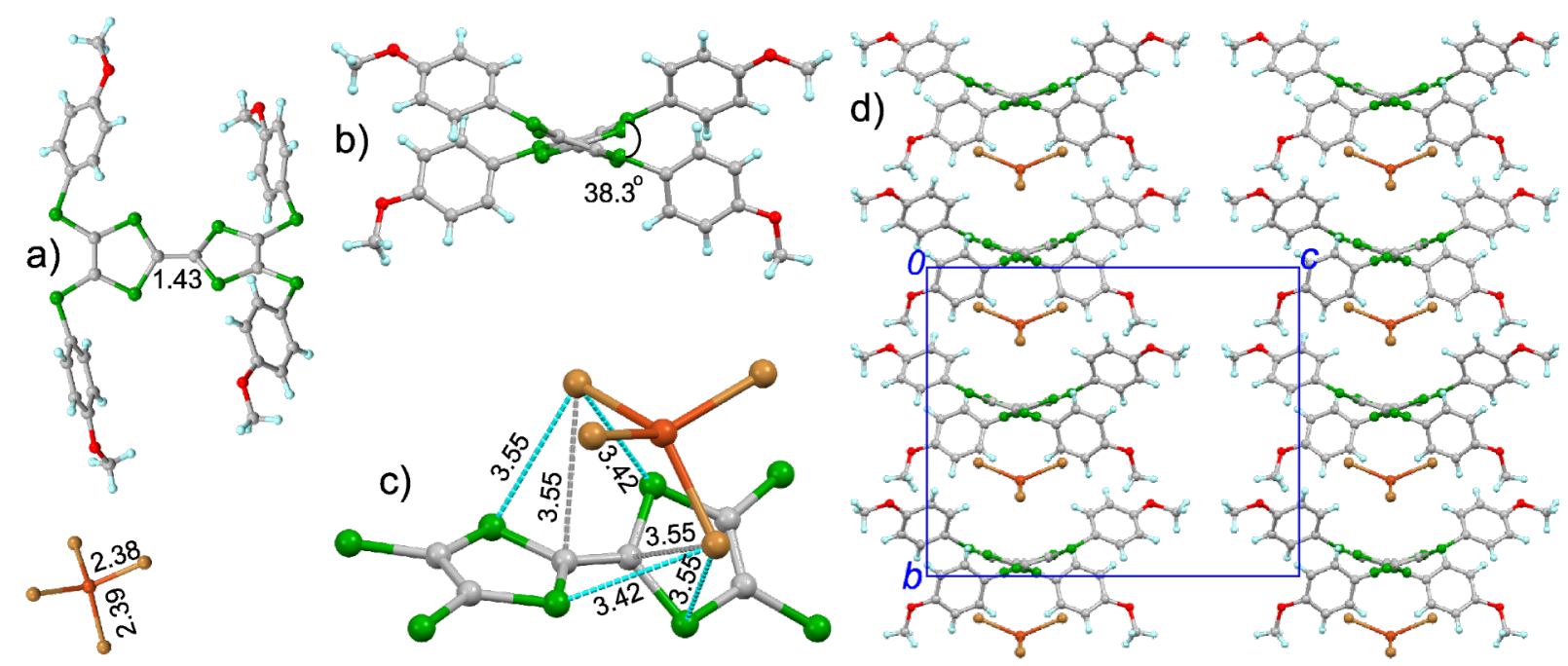

Figure 3: Crystal structure of $4 \cdot \mathrm{CuBr}_{4}$ : a) unit cell contents with the typical bond lengths shown $(\AA)$; b) view of molecule 4 along the central $\mathrm{C}=\mathrm{C}$ bond of the TTF core, and the dihedral angle between two $\mathrm{C}_{3} \mathrm{~S}_{2}$ rings is shown; $\mathrm{c}$ ) interaction between the $\left[\mathrm{Cu}(\mathrm{II}) \mathrm{Br}_{4}\right]^{2-}$ ion and the central TTF core of 4 , where cyan and grey dashed lines represent $\mathrm{Br}^{\cdots} \mathrm{S}$ and $\mathrm{Br}{ }^{\cdots} \mathrm{C}$ contacts $(\AA)$, respectively; d) packing structure viewed along the $a$-axis.

dihedral angle of $38.3^{\circ}$ as shown in Figure $3 \mathrm{~b}$. The $\mathrm{CuBr}_{4}$ component shows the tetrahedral conformation with a $\mathrm{Cu}-\mathrm{Br}$ bond length of 2.38 and $2.39 \AA$, thus $\mathrm{CuBr}_{4}$ is a dianion. The $\left[\mathrm{CuBr}_{4}\right]^{2-}$ ion locates above the donor molecule, and there are $\mathrm{Br} \cdots \mathrm{S}(3.42-3.55 \AA)$ and $\mathrm{Br}{ }^{\cdots} \mathrm{C}$ contacts $(3.55 \AA)$ between the $\left[\mathrm{CuBr}_{4}\right]^{2-}$ ion and $\mathbf{4}$ as shown in Figure 3c. Molecule $\mathbf{4}$ and the
$\left[\mathrm{CuBr}_{4}\right]^{2-}$ ion form the mixed aggregation along the $b$-axis (Figure 3d). Although there is no interaction between the neighbouring donor molecules in the $b c$-plane, the $\mathrm{S} \cdots \mathrm{S}$ contacts $(3.22 \AA)$ are observed between the molecules of 4 along the $a$-axis direction, which would result in the spin exchange interaction between $\mathrm{Cu}$ (II). 
5. $\mathrm{Cu}_{2} \mathrm{Br}_{6}$ crystallizes in the triclinic $P-1$ space group with half of molecule 5 and half of $\mathrm{Cu}_{2} \mathrm{Br}_{6}$ crystallographically independent (Figure 4a). The central TTF core of $\mathbf{5}$ adopts the planar conformation, and the $\delta$ value of $\mathbf{5}$ in the salt is 0.595 , indicating that $\mathbf{5}$ is oxidized to the dication form. As for the inorganic component $\mathrm{Cu}_{2} \mathrm{Br}_{6}$, two $\mathrm{Cu}$ atoms are connected by two bromine bridges ( $\mathrm{Br}-\mathrm{Cu}$ bond length: $2.47 \AA$ ) to form a quasi-planar dianion $\left[\mathrm{Cu}_{2} \mathrm{Br}_{6}\right]^{2-}$. Thus, the spin exchange interaction between these two $\mathrm{Cu}(\mathrm{II})$ would be significant, as discussed in the following section. Molecule 5 and the $\left[\mathrm{Cu}_{2} \mathrm{Br}_{6}\right]^{2-}$ ion form the mixed aggregation along the $b$-axis as shown in Figure 4b. There is no atomic close contact between the organic and inorganic components in a stacking column, whereas one $\mathrm{S} \cdots \mathrm{S}$ contact $(3.57 \AA)$ is observed between the neighbouring molecules of $\mathbf{5}$ along their longitudinal axis.

6. $\mathrm{CuBr}_{2} \cdot \mathrm{CH}_{3} \mathrm{CN}$ crystallizes in the triclinic $P-1$ space group, and the asymmetric unit contains half of molecule $\mathbf{6}$, half of
$\mathrm{CuBr}_{2}$, and half of a $\mathrm{CH}_{3} \mathrm{CN}$ solvent molecule (Figure 5a). The central TTF core of 6 has a pseudo-planar conformation, and the calculated $\delta$ value of 6 in the salt is 0.744 , indicating that 6 is in the radical cation form. The inorganic component $\mathrm{CuBr}_{2}$ is linear, and the $\mathrm{Cu}-\mathrm{Br}$ bond length is $2.54 \AA$, which is close to that of a typical $\mathrm{Cu}(\mathrm{I})-\mathrm{Br}$ bond [51-53,56-58], indicating that $\mathrm{CuBr}_{2}$ has the charge of -1 . The organic and inorganic components form the mixed stacks along the $a$-axis as shown in Figure $5 \mathrm{~b}$. Moreover, the peripheral aryl groups form the cavity to accommodate a $\mathrm{CH}_{3} \mathrm{CN}$ solvent molecule, thus a supramolecular framework is formed in this salt. In the salt of 7 with $\mathrm{CuBr}_{2}$, molecule 7 is also oxidized to the radical cation form and the counter anion is $\left[\mathrm{CuBr}_{2}\right]^{-}$as shown in Supporting Information File 1 (Figure S11).

\section{Magnetic properties}

The temperature-dependent magnetic susceptibilities of the salts were measured on the polycrystalline samples. In the salts of

a)
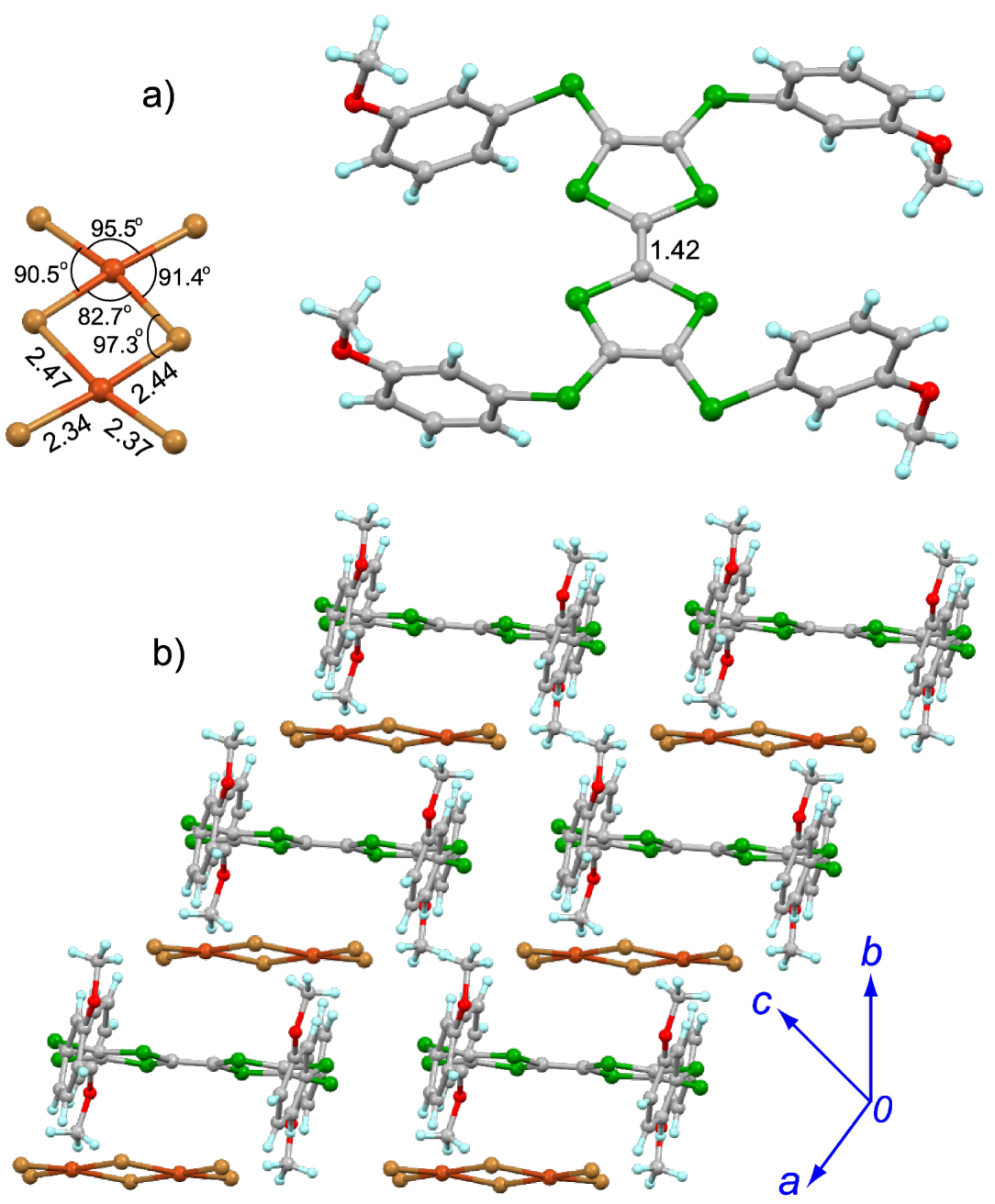

Figure 4: Crystal structure of $5 \cdot \mathrm{Cu}_{2} \mathrm{Br}_{6}$ : a) unit cell contents with the numeric data indicate the angles and bond lengths ( $\AA$ ); b) packing structure. 


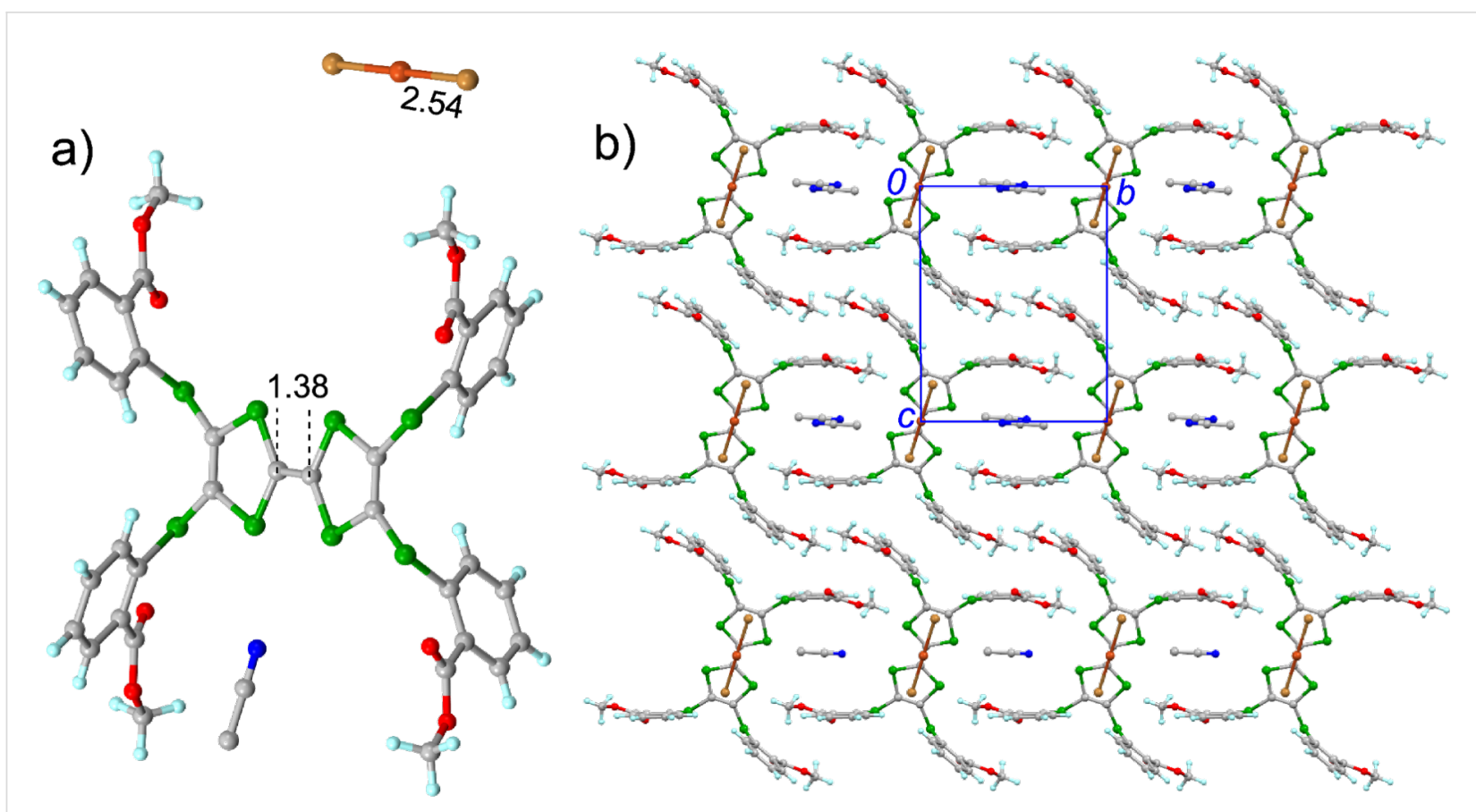

Figure 5: Crystal structure of $6 \cdot \mathrm{CuBr}_{2} \cdot \mathrm{CH}_{3} \mathrm{CN}$ : a) unit cell contents with the typical bond lengths shown $(\AA)$; b) packing structure viewed along the crystallographic a-axis.

1-5, the spin susceptibility comes from $\mathrm{Cu}(\mathrm{II})(S=1 / 2)$, because the TTFs in these salts are oxidized to the dication form and the inorganic components contain $\mathrm{Cu}(\mathrm{II})$. On the other hand, spin susceptibility on the salts of $\mathbf{6}$ and 7 originates from the radical cation, as the inorganic components in these salts contain $\mathrm{Cu}(\mathrm{I})$. Figure 6 depicts the temperature-dependent magnetic susceptibilities of the representative salts.

1. $\mathrm{CuBr}_{4}, \mathbf{2} \cdot \mathrm{CuBr}_{4}, \mathbf{4} \cdot \mathrm{CuBr}_{4}$, and $7 \cdot \mathrm{CuBr}_{2}$ show the similar magnetic properties. The temperature dependence of the magnetic susceptibility follows the Curie-Weiss law, and the spins in these salts show the antiferromagnetic interaction at low temperature. The antiferromagnetic interactions of $\mathrm{Cu}$ (II) in $\mathbf{1} \cdot \mathrm{CuBr}_{4}, \mathbf{2} \cdot \mathrm{CuBr}_{4}$, and $\mathbf{4} \cdot \mathrm{CuBr}_{4}$ arise from the $d-\pi-d$ pathway, as discussed in the crystal structure section. On the other hand, the antiferromagnetic interaction of radical cations in $7 \cdot \mathrm{CuBr}_{2}$ could be due to the $\pi-\pi$ interactions, because the neighbouring donor molecules have a $\mathrm{S} \cdots \mathrm{S}$ contact (3.30 $\AA$ ) along the $a$-axis. Figure 6 a shows the magnetic susceptibility of $1 \cdot \mathrm{CuBr}_{4}$ by varying temperature, and the best-fitting parameters for this salt are $C=0.382 \mathrm{emu} \mathrm{K} \mathrm{mol}{ }^{-1}$ and $\theta=-5.4 \mathrm{~K}$.

In the case of $\mathbf{3} \cdot\left(\mathrm{CuBr}_{4}\right)_{0.5} \cdot \mathrm{CuBr}_{3} \cdot \mathrm{THF}$, the temperature dependence of magnetic susceptibility shows the monotonic decrement upon cooling in the temperature range of 300-270 K. Furthermore, an abrupt jump of the magnetic susceptibility is observed at $270 \mathrm{~K}$ (see Figure $6 \mathrm{~b}$ ). This abrupt jump could be attributed to the variation of intermolecular interactions as discussed in the crystal structure section. Below $270 \mathrm{~K}$, the temperature dependence of magnetic susceptibility follows the Curie-Weiss law with $C=0.379 \mathrm{emu} \mathrm{K} \mathrm{mol}{ }^{-1}$ and $\theta=-4.6 \mathrm{~K}$.

As mentioned in the crystal structure section, two $\mathrm{Cu}(\mathrm{II})$ atoms in $5 \cdot \mathrm{Cu}_{2} \mathrm{Br}_{6}$ are connected by two bromine bridges, which result in the strong spin interaction between $\mathrm{Cu}(\mathrm{II})$ atoms. The temperature-dependent magnetic susceptibility of $\mathbf{5} \cdot \mathrm{Cu}_{2} \mathrm{Br}_{6}$ is shown in Figure 6c, which can be well-fitted by the singlet-triplet model [60]. The best-fitting parameters are: $J=-243 \mathrm{~K}$ which is consistent with the significant magnetic susceptibility dropping at $245 \mathrm{~K}, f=0.993$, and $A=3.21 \times 10^{-4} \mathrm{emu} \mathrm{mol}^{-1}$. The latter two terms reflect the non-zero magnetic susceptibility originated from the crystal defects (the Curie term) and the residue paramagnetic impurities.

$$
\chi_{\text {calcd }}=f \cdot \frac{2 N_{\mathrm{A}} g^{2} \mu_{\mathrm{B}}}{k_{\mathrm{B}} T} \cdot \frac{1}{3+\exp \left(-\frac{2 J}{k_{\mathrm{B}} T}\right)}+(1-f) \cdot \frac{C}{T}+A
$$

\section{Conclusion}

We have reported the synthesis, structures, and magnetic properties of the copper ion salts of Ar-S-TTFs 1-7. The present salts show a wide variety of solid state structures and magnetic 


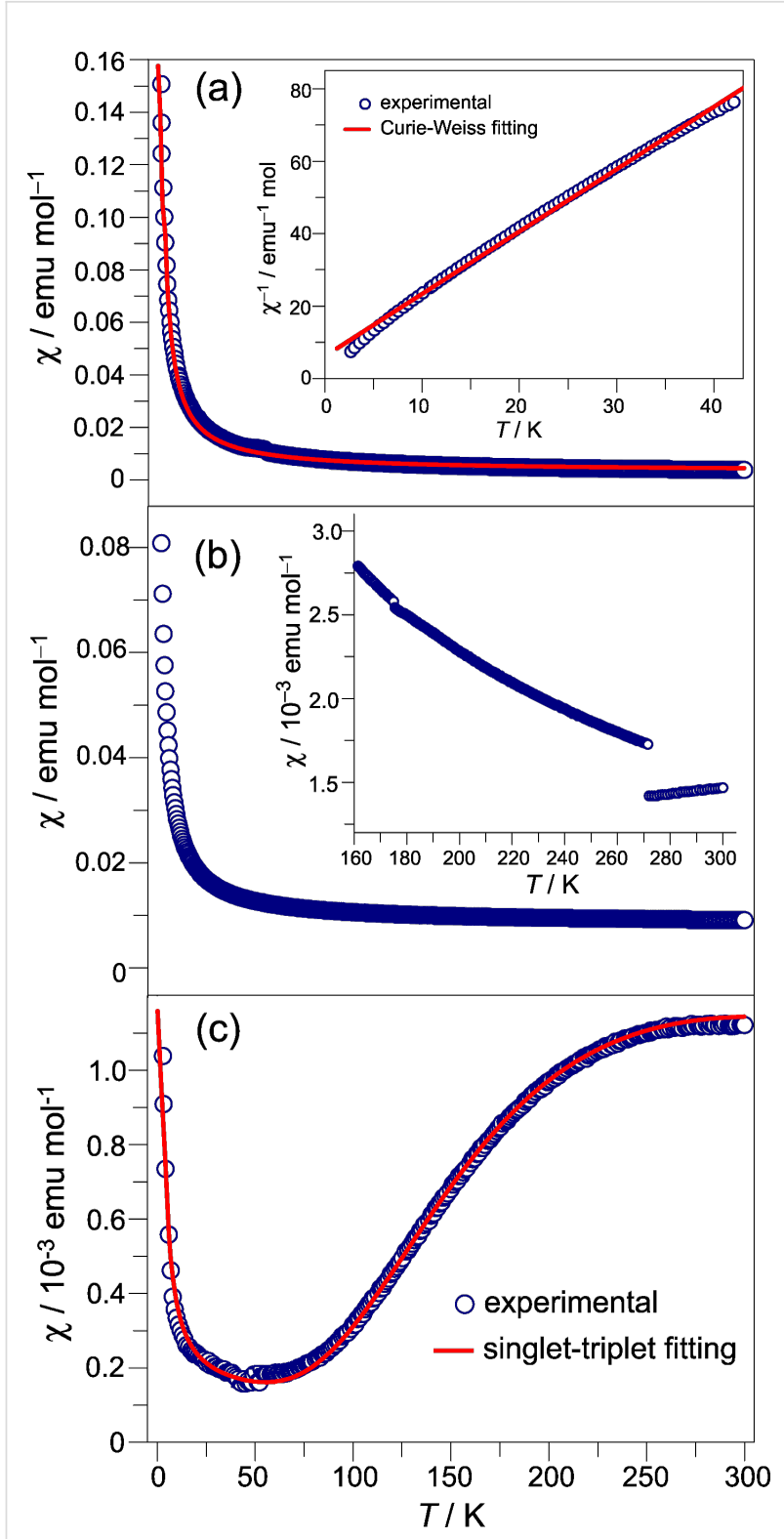

Figure 6: Temperature dependent magnetic susceptibility for the typical salts: a) $1 \cdot \mathrm{CuBr}_{4}$ with the insert panel depicting the Curie-Weiss fitting (red solid line) in low temperature region; b) $3 \cdot\left(\mathrm{CuBr}_{4}\right)_{0.5} \cdot \mathrm{CuBr}_{3} \cdot \mathrm{THF}$ with the insert panel depicting the magnetic susceptibility at high temperature region; c) $5 \cdot \mathrm{Cu}_{2} \mathrm{Br}_{6}$ with the red solid line depicting the singlet-triplet fitting.

properties. The charge on TTFs in the salts depends on their second redox potentials $\left(E_{1 / 2}{ }^{2}\right): E_{1 / 2}{ }^{2}>0.90 \mathrm{~V}$, radical cation; $E_{1 / 2}{ }^{2}<0.90 \mathrm{~V}$, dication. Except compound 4, which has the twisted central TTF core in the dicationic salt $4 \cdot \mathrm{CuBr}_{4}$, the central TTF frameworks of these TTFs are nearly planar despite the charge on them. On the other hand, the anions in the salts show various configurations including the linear $\left[\mathrm{Cu}(\mathrm{I}) \mathrm{Br}_{2}\right]^{-}$ ion, the tetrahedral $\left[\mathrm{Cu}(\mathrm{II}) \mathrm{Br}_{4}\right]^{2-}$ ion, the planar $\left[\mathrm{Cu}(\mathrm{II})_{2} \mathrm{Br}_{6}\right]^{2-}$ ion, the planar $\left[\mathrm{Cu}(\mathrm{II}) \mathrm{Br}_{4}\right]^{2-}$ ion, and the distorted tetrahedral
$\left[\mathrm{Cu}(\mathrm{II}) \mathrm{Br}_{3} \cdot \mathrm{THF}\right]^{-}$ion. As a result of diverse geometries for both donor molecules and counter anions, the present salts show various packing structures, which results in a different spin-exchange interaction pathway as proved by their magnetic properties.

\section{Experimental}

Cupric bromide $\left(\mathrm{CuBr}_{2}\right)$ was purchased from Shanghai Xinbao Fine Chemical Factory (Shanghai, China). Tetrahydrofuran (THF) and acetonitrile $\left(\mathrm{CH}_{3} \mathrm{CN}\right)$ were distilled over $\mathrm{CaH}_{2}$ and stored under $\mathrm{N}_{2}$ atomsphere. Compounds 1-7 were synthesized by following our previous reports [37,38].

The electrochemical properties of 1-7 were recorded on a RST 5000 electrochemical workstation at a scan rate of $50 \mathrm{mV} \mathrm{s}^{-1}$, with glassy carbon discs as the working electrode, Pt wire as the counter electrode, and a SCE electrode as the reference electrode. The concentration was $5 \times 10^{-4} \mathrm{~mol} \mathrm{~L}^{-1}$ in $\mathrm{CH}_{2} \mathrm{Cl}_{2}$, and the supporting electrolyte was $(n-\mathrm{Bu})_{4} \mathrm{~N} \cdot \mathrm{PF}_{6}\left(0.1 \mathrm{~mol} \mathrm{~L}{ }^{-1}\right)$. The measurement was performed at $20{ }^{\circ} \mathrm{C}$ after bubbling the solution with $\mathrm{N}_{2}$ gas for $15 \mathrm{~min}$.

The X-ray diffraction measurement was carried out on SuperNova (Agilent) type diffractometer. The crystal structure was solved by a direct method SIR2004 [61] and refined by a fullmatrix least-squares method on $F^{2}$ by means of SHELXL-97 [62]. The X-ray powder diffraction (XRPD) pattern was recorded on X'Pert PRO (PANalytical). The temperature dependence of the magnetic susceptibility was measured on a SQUID magnetometer of Quantum Design MPMS-XL applying a magnetic field of $1 \mathrm{kOe}$. The data were corrected for core diamagnetism estimated from the sum of the Pascal constants [63].

\section{Supporting Information}

\section{Supporting Information File 1}

Selected crystallographic data, crystal structures of $\mathbf{2} \cdot \mathrm{CuBr}_{4}$ and $7 \cdot \mathrm{CuBr}_{2}$, and variations of molecular geometries of

TTFs at different oxidation states.

[http://www.beilstein-journals.org/bjoc/content/ supplementary/1860-5397-11-95-S1.pdf]

\section{Supporting Information File 2}

Crystallographic data files of compounds 1-7. These data have been deposited to the Cambridge Crystallographic Data Centre (CCDC) with the registered numbers 1046215-1046222.

[http://www.beilstein-journals.org/bjoc/content/ supplementary/1860-5397-11-95-S2.cif] 


\section{Acknowledgements}

This work was financially supported by National Natural Science Foundation of China (21372111 and 21172104) and Research Fund for the Doctoral Program of Higher Education of China (RFDP 20120211110039). We are grateful to Prof. Bin Chen (Hangzhou Normal University) for the measurement of magnetic susceptibility.

\section{References}

1. Wudl, F.; Smith, G. M.; Hufnagel, E. J. J. Chem. Soc. D 1970, 1453-1454. doi:10.1039/C29700001453

2. Yamada, J.; Sugimoto, T., Eds. TTF Chemistry Fundamentals and Applications of Tetrathiafulvalene; Kodansha Springer: Berlin, Germany, 2004.

3. Ferraris, J.; Cowan, D. O.; Walatka, V.; Perlstein, J. H. J. Am. Chem. Soc. 1973, 95, 948-949. doi:10.1021/ja00784a066

4. Jérome, D.; Mazaud, A.; Ribault, M.; Bechgaard, K. J. Phys., Lett. 1980, 41, 95-98. doi:10.1051/jphyslet:0198000410409500

5. Williams, J. M.; Ferraro, J. R.; Thorn, R. J.; Carlson, K. D.; Geiser, U.; Wang, H. H.; Kini, A. M.; Whangbo, M.-H. Organic Superconductors (including Fullerenes); Prentice Hall: Englewood Cliffs, NJ, 1992.

6. Ishiguro, T.; Yamaji, K.; Saito, G. Organic Superconductors, 2nd ed.; Springer: Berlin, Germany, 1998.

7. Batail, P., Ed. Molecular Conductors. Chem. Rev. 2004, 104, 4887-5782.

8. Kagoshima, S.; Kanoda, K.; Mori, T., Eds. Organic Conductors. J. Phys. Soc. Jpn. 2006, 75, 051001-051802.

9. Lebed, A., Ed. The Physics of Organic Superconductors and Conductors; Springer: Berlin, Germany, 2008.

10. Ardavan, A.; Brown, S.; Kagoshima, S.; Kanoda, K.; Kuroki, K.; Mori, H.; Ogata, M.; Uji, S.; Wosnitza, J. J. Phys. Soc. Jpn. 2012, 81, 011004. doi:10.1143/JPSJ.81.011004

11. Ota, A.; Yamochi, H.; Saito, G. J. Mater. Chem. 2002, 12, 2600-2602. doi:10.1039/B206293C

12. Ota, A.; Yamochi, H.; Saito, G. J. Low Temp. Phys. 2006, 142, 425-428. doi:10.1007/BF02679536

13. Chollet, M.; Guerin, L.; Uchida, N.; Fukuya, S.; Shimoda, H.; Ishikawa, T.; Matsuda, K.; Hasegawa, T.; Ota, A.; Yamochi, H.; Saito, G.; Tazaki, R.; Adachi, S.-i.; Koshihara, S.-y. Science 2005, 307, 86-89. doi:10.1126/science.1105067

14. Onda, K.; Ogihara, S.; Yonemitsu, K.; Maeshima, N.; Ishikawa, T.; Okimoto, Y.; Shao, X.; Nakano, Y.; Yamochi, H.; Saito, G.; Koshihara, S.-y. Phys. Rev. Lett. 2008, 101, 067403. doi:10.1103/PhysRevLett.101.067403

15. Gao, M.; Lu, C.; Jean-Ruel, H.; Liu, L. C.; Marx, A.; Onda, K.; Koshihara, S.-y.; Nakano, Y.; Shao, X.; Hiramatsu, T.; Saito, G.; Yamochi, H.; Cooney, R. R.; Moriena, G.; Sciaini, G.; Miller, R. J. D. Nature 2013, 496, 343-346. doi:10.1038/nature12044

16. Shao, X.; Nakano, Y.; Yamochi, H.; Dubrovskiy, A. D.; Otsuka, A.; Murata, T.; Yoshida, Y.; Saito, G.; Koshihara, S.-y. J. Mater. Chem. 2008, 18, 2131-2140. doi:10.1039/B717621J

17. Shao, X.; Nakano, Y.; Sakata, M.; Yamochi, H.; Yoshida, Y.; Maesato, M.; Uruichi, M.; Yakushi, K.; Murata, T.; Otsuka, A.; Saito, G.; Koshihara, S.-y.; Tanaka, K. Chem. Mater. 2008, 20, 7551-7562. doi:10.1021/cm802517s

18. Shao, X.; Yoshida, Y.; Nakano, Y.; Yamochi, H.; Sakata, M.; Maesato, M.; Otsuka, A.; Saito, G.; Koshihara, S.-y. Chem. Mater. 2009, 21, 1085-1095. doi:10.1021/cm803180x
19. Murata, T.; Shao, X.; Nakano, Y.; Yamochi, H.; Uruichi, M.; Yakushi, K.; Saito, G.; Tanaka, K. Chem. Mater. 2010, 22, 3121-3132. doi:10.1021/cm100051b

20. Bryce, M. R. Chem. Soc. Rev. 1991, 20, 355-390. doi:10.1039/CS9912000355

21. Adam, M.; Müllen, K. Adv. Mater. 1994, 6, 439-459. doi:10.1002/adma.19940060603

22. Jørgensen, T.; Hansen, T. K.; Becher, J. Chem. Soc. Rev. 1994, 23, 41-51. doi:10.1039/CS9942300041

23. Bryce, M. R. J. Mater. Chem. 1995, 5, 1481-1496. doi:10.1039/JM9950501481

24. Garín, J. Adv. Heterocycl. Chem. 1995, 62, 249-304. doi:10.1016/S0065-2725(08)60423-7

25. Otsubo, T.; Aso, Y.; Takimiya, K. Adv. Mater. 1996, 8, 203-211. doi:10.1002/adma.19960080303

26. Coronado, E.; Gómez-García, C. J. Chem. Rev. 1998, 98, 273-296. doi:10.1021/cr970471c

27. Bryce, M. R. Adv. Mater. 1999, 11, 11-23. doi:10.1002/(SICI)1521-4095(199901)11:1<11::AID-ADMA11>3.0.CO; 2-3

28. Nielsen, M. B.; Lomholt, C.; Becher, J. Chem. Soc. Rev. 2000, 29, 153-164. doi:10.1039/A803992E

29. Segura, J. L.; Martín, N. Angew. Chem., Int. Ed. 2001, 40, 1372-1409. doi:10.1002/1521-3773(20010417)40:8<1372::AID-ANIE1372>3.0.CO; 2-I

30. Frère, P.; Skabara, P. J. Chem. Soc. Rev. 2005, 34, 69-98. doi:10.1039/B316392J

31. Canavet, D.; Sallé, M.; Zhang, G.; Zhang, D.; Zhu, D. Chem. Commun. 2009, 2245-2269. doi:10.1039/B818607N

32. Ding, H.; Li, Y.; H, H.; Sun, Y.; Wang, J.; Wang, C.; Wang, C.; Zhang, G.; Wang, B.; Xu, W.; Zhang, D. Chem. - Eur. J. 2014, 20, 14614. doi:10.1002/chem. 201405330

33. Skabara, P. J.; Serebryakov, I. M.; Roberts, D. M.; Perepichka, I. F.; Coles, S. J.; Hursthouse, M. B. J. Org. Chem. 1999, 64, 6418-6424. doi:10.1021/jo990198+

34. Skabara, P. J.; Roberts, D. M.; Serebryakov, I. M.; Pozo-Gonzalo, C. Chem. Commun. 2000, 1005-1006. doi:10.1039/B001943G

35. Berridge, R.; Serebryakov, I. M.; Skabara, P. J.; Ortí, E.; Viruela, R.; Pou-Amérigo, R.; Coles, S. J.; Hursthouse, M. B. J. Mater. Chem. 2004, 14, 2822-2830. doi:10.1039/B404545A

36. Kanibolotsky, A. L.; Kanibolotskaya, L.; Gordeyev, S.; Skabara, P. J.; McCulloch, I.; Berridge, R.; Lohr, J. E.; Marchioni, F.; Wudl, F. Org. Lett. 2007, 9, 1601-1604. doi:10.1021/ol070366h

37. Sun, J.; Lu, X.; Shao, J.; Cui, Z.; Shao, Y.; Jiang, G.; Yu, W.; Shao, X. RSC Adv. 2013, 3, 10193-10196. doi:10.1039/C3RA41349G

38. Sun, J.; Lu, X.; Shao, J.; Li, X.; Zhang, S.; Wang, B.; Zhao, J.; Shao, Y.; Fang, R.; Wang, Z.; Yu, W.; Shao, X. Chem. - Eur. J. 2013, 19, 12517-12525. doi:10.1002/chem.201301819

39. Lu, X.; Sun, J.; Liu, Y.; Shao, J.; Ma, L.; Zhang, S.; Zhao, J.; Shao, Y.; Zhang, H.-L.; Wang, Z.; Shao, X. Chem. - Eur. J. 2014, 20, 9650-9656. doi:10.1002/chem.201402327

40. Sun, J.; Lu, X.; Ishikawa, M.; Nakano, Y.; Zhang, S.; Zhao, J.; Shao, Y.; Wang, Z.; Yamochi, H.; Shao, X. J. Mater. Chem. C 2014, 2, 8071-8076. doi:10.1039/C4TC01362J

41. Lu, X.; Sun, J.; Zhang, S.; Ma, L.; Qi, H.; Liu, L.; Shao, Y. Beilstein J. Org. Chem. submitted. The combination of Ar-S-TTFs with fullerenes resulted in various type of donor-acceptor type co-crystals. 
42. Ma, L.; Lu, X.; Sun, J.; Liu, L.; Qi, H.; Shao, X. to be submitted. The combination of Ar-S-TTFs with TCNQ resulted in the neutral complexes, and that with $\mathrm{F}_{4} \mathrm{TCNQ}$ afforded the partially transferred and/or ionic complexes.

43. Zhang, S.; Lu, X.; Sun, J.; Zhao, Y.; Shao, Y.; Shao, X. CrystEngComm 2015, 17. doi:10.1039/C5CE00510H

The supramolecular assembly of Ar-S-TTF with Keggin-type phosphomolybdic acid resulted in the honey-comb supramolecular frameworks.

44. Siedle, A. R.; Candela, G. A.; Finnegan, T. F.; Van duyne, R. P.; Cape, T.; Kokoszka, G. F.; Woyciejes, P. M.; Hashmall, J. A. Inorg. Chem. 1981, 20, 2635-2640. doi:10.1021/ic50222a049

45. Inoue, M. B.; Inoue, M.; Fernando, Q.; Nebesny, K. W. Inorg. Chem. 1986, 25, 3976-3980. doi:10.1021/ic00242a030

46. Day, P.; Kurmoo, M.; Mallah, T.; Marsden, I. R.; Friend, R. H.; Pratt, F. L.; Hayes, W.; Chasseau, D.; Gaultier, J. J. Am. Chem. Soc. 1992, 114, 10722-10729. doi:10.1021/ja00053a007

47. Marsden, I. R.; Allan, M. L.; Friend, R. H.; Kurmoo, M.; Kanazawa, D.; Day, P.; Bravic, G.; Chasseau, D.; Ducasse, L.; Hayes, W. Phys. Rev. B 1994, 50, 2118-2127. doi:10.1103/PhysRevB.50.2118

48. Iwamatsu, M.; Kominami, T.; Ueda, K.; Sugimoto, T.; Adachi, T.; Fujita, H.; Yoshino, H.; Mizuno, Y.; Murata, K.; Shiro, M. Inorg. Chem. 2000, 39, 3810-3815. doi:10.1021/ic0001098

49. Kanehama, R.; Umemiya, M.; Iwahori, F.; Miyasaka, H.; Sugiura, K.-i.; Yamashita, M.; Yokochi, Y.; Ito, H.; Kuroda, S.; Kishida, H.; Okamoto, H. Inorg. Chem. 2003, 42, 7173-7181. doi:10.1021/ic0344362

50. Matsumoto, T.; Kamada, Y.; Sugimoto, T.; Tada, T.; Noguchi, S.; Nakazumi, H.; Kawakami, T.; Yamaguchi, K.; Shiro, M. Inorg. Chem. 2003, 42, 8638-8645. doi:10.1021/ic0300971

51. Lu, W.; Zhu, Q.-Y.; Dai, J.; Zhang, Y.; Bian, G.-Q.; Liu, Y.; Zhang, D.-Q. Cryst. Growth Des. 2007, 7, 652-657. doi:10.1021/cg060490s

52. Ichikawa, S.; Kimura, S.; Takahashi, K.; Mori, H.; Yoshida, G.; Manabe, Y.; Matsuda, M.; Tajima, H.; Yamaura, J. Inorg. Chem. 2008, 47, 4140-4145. doi:10.1021/ic7019632

53. Wang, Y.; Cui, S.; Li, B.; Zhang, J.; Zhang, Y. Cryst. Growth Des. 2009, 9, 3855-3858. doi:10.1021/cg900635f

54. Ichikawa, S.; Takahashi, K.; Matsuda, M.; Tajima, H.; Mori, H. J. Mater. Chem. 2010, 20, 10130-10134. doi:10.1039/C0JM01318H

55. Guionneau, P.; Kepert, C. J.; Bravic, G.; Chasseau, D.; Truter, M. R.; Kurmoo, M.; Day, P. Synth. Met. 1997, 86, 1973-1974. doi:10.1016/S0379-6779(97)80983-6

56. Pavlyuka, O.; Lis, T.; Mys'kiv, M. G. Z. Anorg. Allg. Chem. 2005, 631, 1893-1897. doi:10.1002/zaac.200500057

57. Beck, J.; de Oliveira, A. B. Z. Anorg. Allg. Chem. 2009, 635, 445-449. doi:10.1002/zaac.200801306

58. Kubo, K.; Yamashita, M. Crystals 2012, 2, 284-293. doi:10.3390/cryst2020284

59. Bondi, A. J. Phys. Chem. 1964, 68, 441-451. doi:10.1021/j100785a001

60. Kahn, O. Molecular Magnetism; Wiley-VCH: Weinheim, Germany, 1993.

61. Burla, M. C.; Caliandro, R.; Camalli, M.; Carrozzini, B.; Cascarano, G. L.; de Caro, L.; Giacovazzo, C.; Polidori, G.; Spagna, R. J. Appl. Crystallogr. 2005, 38, 381-388. doi:10.1107/S002188980403225X

62. SHELXL-97, A Program for Crystal Structure Refinement; University of Göttingen: Göttingen, 1997.

63. Gupta, R. R. Diamagnetism Susceptibility. In Landolt-Börnstein, New Series II; Hellwege, K. H.; Hellwege, A. M., Eds.; Springer: Berlin, Germany, 1986; Vol. 16.

\section{License and Terms}

This is an Open Access article under the terms of the Creative Commons Attribution License

(http://creativecommons.org/licenses/by/2.0), which permits unrestricted use, distribution, and reproduction in any medium, provided the original work is properly cited.

The license is subject to the Beilstein Journal of Organic Chemistry terms and conditions:

(http://www.beilstein-journals.org/bjoc)

The definitive version of this article is the electronic one which can be found at:

doi:10.3762/bjoc. 11.95 